\title{
Determination of Stability During First Impounding in Jatigede Earth Dam
}

\author{
Anafi Minmahddun ${ }^{1}$, Teuku Faisal Fathani ${ }^{* 1,2}$, and Fikri Faris ${ }^{1,2}$ \\ ${ }^{1}$ Department of Civil and Environmental Engineering, Faculty of Engineering, Universitas Gadjah Mada, \\ Yogyakarta, Indonesia \\ ${ }^{2}$ Center for Disaster Mitigation and Technological Innovation (GAMA-InaTek), Universitas Gadjah Mada, \\ Yogyakarta, Indonesia
}

\begin{abstract}
The Jatigede Dam is a multi-purpose rockfill dam located in Sumedang Regency, West Java Province. The construction of the Jatigede Dam started in 2008 and it is the second largest dam in Indonesia after the Jatiluhur Dam. As one of the vital facilities, it is highly necessary to evaluate the stability of the Jatigede Dam to avoid dam collapse. First reservoir filling is one of the factors affecting the dam stability; therefore, this research aims to evaluate the Jatigede Dam stability during impounding. The transient seepage analysis was conducted to evaluate the pore pressure change during impounding. The result of seepage analysis was used to analyze the dam stability using the limit equilibrium method with Rockscience software of Slide2. The results of the seepage analysis shows that the rise of the reservoir water level affects the upstream slope stability. The safety factor of the upstream slope changes during the impounding process. All the safety factors for the upstream and downstream slopes during impounding still meet the minimum safety factor criteria required.
\end{abstract}

Keywords: Rockfill dam · Seepage · Pore water pressure - Slope stability · Safety factor · Slide2.

\section{INTRODUCTION}

The Jatigede dam is a rockfill dam which was built between 2008 and 2015. The dam serves to provide water for about 90,000 ha irrigation area, generate power for 110 MW hydroelectric power plant, control flooding, and supply water for Sumedang, Majalengka, Indramayu, and Cirebon Regency.

Slope stability analysis of the dam is very important to ensure the stability of the structure. One of the factors that influences slope stability is the change of pore pressure. The research conducted by Rulon and Freeze (1985); Iverson (2000); Picarelli et al. (2003); Kohv and Hang (2013) state that the changes in pore water pressure caused by infiltration of rainwater

\footnotetext{
${ }^{*}$ Corresponding author: T.F. FATHANI, Department of Civil and Environmental Engineering, Gadjah Mada University. Jl. Grafika 2 Yogyakarta, Indonesia. E-mail: tfathani@ugm.ac.id
}

can cause slopes instability. Beside the change in pore water pressure, the stability of the dam is also controlled by the geometry and engineering properties of dam material (Afiri and Gabi, 2018).

Water level fluctuation in a reservoir is one of the causing factors of the collapse of the dam body (Yuewe et al., 2005; Fathani and Legono, 2011). The reservoir water seeps into the dam body through the pore between soil particles. The seepage increases pore water pressure and reduces the effective stress of the soil (Yuewe et al., 2005). In addition, reservoir water level that rises rapidly can affect the stability of the upstream and downstream slope of the dam (Fathani and Legono, 2012).

This research aims to evaluate the Jatigede Dam stability during impounding between August 2015 and June 2017. The seepage was analyzed using the finite element method and 
validated using the pore water pressure monitoring result to obtain the results that were close to the actual conditions. The results of the seepage analysis were used to analyze the stability of the dam to obtain the safety factor during impounding. Both the seepage analysis and stability analysis were carried out using Rocscience software of Slide2.

\section{CHARACTERISTICS OF THE JATIGEDE DAM}

The Jatigede Dam is the second largest dam in Indonesia after the Jatiluhur Dam in West Java. The watershed area of the Jatigede Reservoir is $1,462 \mathrm{~km}^{2}$ with an annual flow volume of $2.5 \times$ $10^{9} \mathrm{~m}^{3}$. The crest of the dam is at El. $+265 \mathrm{~m}$, the length of the dam's crest is $1,715 \mathrm{~m}$, the crest width of the dam is $12 \mathrm{~m}$, the height of the dam from the lowest elevation is $114 \mathrm{~m}$, the slope of the upstream is $1 \mathrm{~V}: 2 \mathrm{H}$, and the slope of the downstream is $1 \mathrm{~V}: 1.9 \mathrm{H}$.

The main dam was constructed over claystone and volcanic breccia. The reservoir was distributed on shale with intercalation of claystone and sandstone on Upper Cinambo Formation (Thong, 2013). The Jatigede Dam was divided into 6 zones. Zone 1 is an impervious zone consisting of a mixture of soil and gravel with a composition of $70 \%: 30 \%$, zone $2 \mathrm{a}$ is a fine filter with a thickness of $50 \mathrm{~cm}$, zone $2 \mathrm{~b}$ is a coarse filter with a thickness of $50 \mathrm{~cm}$, zone $3 a$ is rockfill with a maximum size of $40 \mathrm{~cm}$, zone $3 \mathrm{~b}$ is a rockfill with a maximum size of $80 \mathrm{~cm}$, and zone 6 is a riprap with a maximum size of $100 \mathrm{~cm}$. The Jatigede Dam was built on a volcanic breccia layer (zone 5) and at the bottom of the dam there is a grouting curtain (zone 4). The plan view and cross section of the Jatigede Dam are shown in Figure 1 and Figure 2.

\section{Research Methods}

The dam was modeled using the cross section in Figure 2. The engineering properties of the dam were determined by series of primary and secondary data from the Ministry of Public Works and Public Housing as seen in Table 1. In this research, coupled analyses of seepage and slope stability were conducted using Rockscience of Slide2. The changes in pore water pressure obtained from the seepage analysis were used in the stability analysis to determine the safety factor of the slope during the reservoir impounding process.

The seepage analysis was carried out using the Finite Element Method while the slope stability analysis was performed using the Limit Equilibrium Method. Among various methods of analysis in the Limit Equilibrium Method such as modified Bishop's method (Bishop, 1954), Janbu's generalized procedure of Slices (Janbu, 1973), Morgenstern and Price's method (Morgenstern and Price, 1965), and Spencer's method (Spencer, 1967), the Morgenstern-Price method was chosen for the analysis because this method uses two basic concepts in determining safety factor, namely equilibrium of forces and moments (Abramson et al., 2002). In addition, this method can be used on slopes with non-circular slip surface (Craig, 2004).

\section{Results AND Discussion}

\subsection{Seepage analysis}

Seepage analysis can be divided into steady state analysis and transient analysis. The steady State analysis is when the inflow is always equal to the outflow within the analysis range. The Transient analysis, on the other hand, can display different inflow and outflow with time. In this research, transient boundary conditions were applied because the reservoir water level changed in the time function (Fredlund and Rahardjo, 1993; Andreea, 2016). The seepage analysis was conducted at the area where the piezometers were installed (PP.8, PP.9, PP.10 and PP.11) as seen in Figure 3. The boundary condition was a simplification of the monitoring results of reservoir water level fluctuations (Figure 4) by selecting a number of points that represented the condition of the water level during the reservoir impounding process. The results of seepage analysis during reservoir impounding are shown in Figure 5.

As seen in Figure 5, the increase in reservoir water level causes an increase in the pore water pressure of the upstream slope of the dam (PP.8, PP.9 and PP.10). However, this change does not occur on the downstream side after zone 1 of the dam (PP.11). The core of the dam with low permeability causes the seepage flow to be deflected when it passes through zone 1 . The seepage flow moves downward because seepage flows from the areas with high per- 


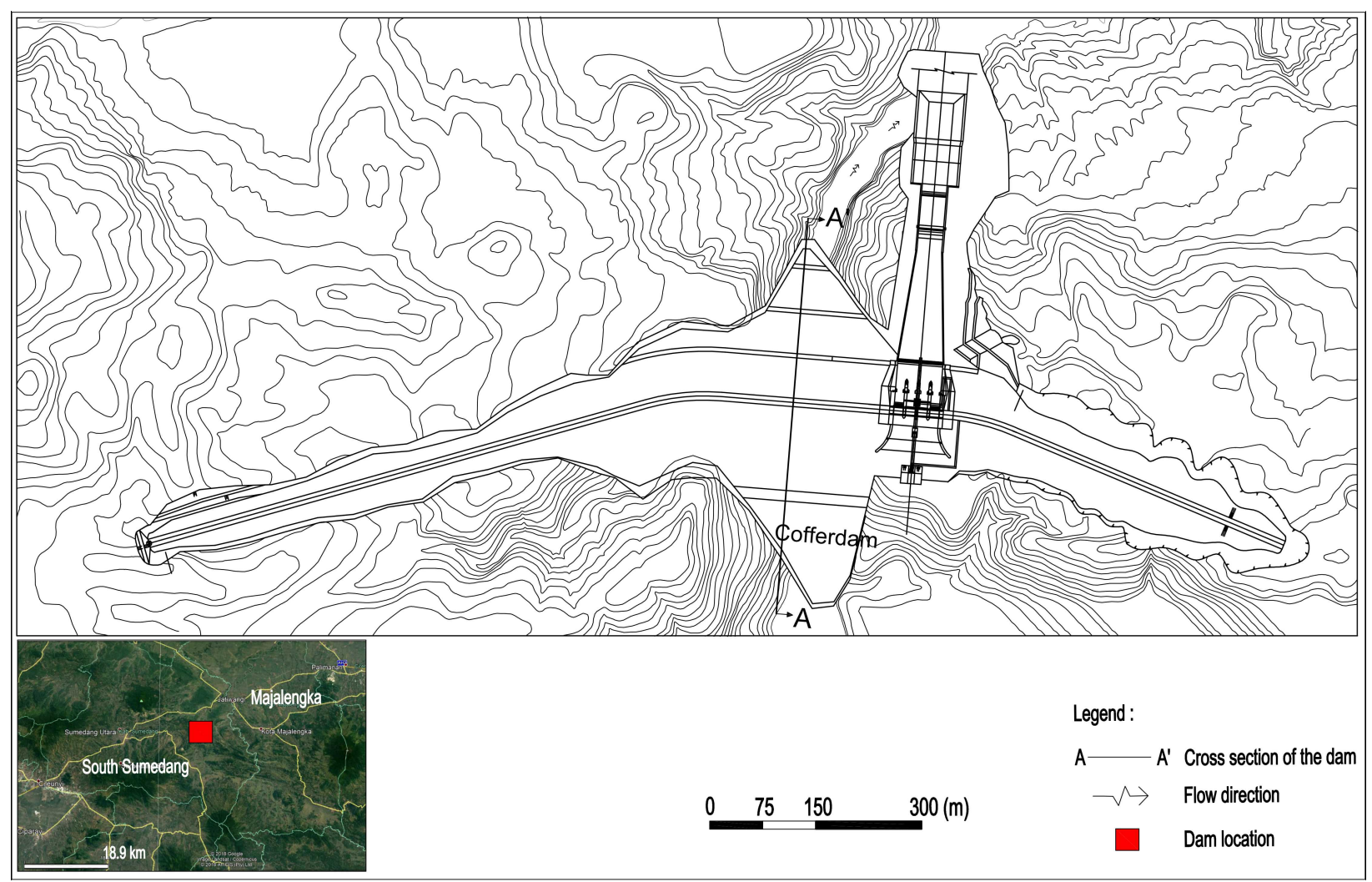

Figure 1: Plan view of the Jatigede Dam.

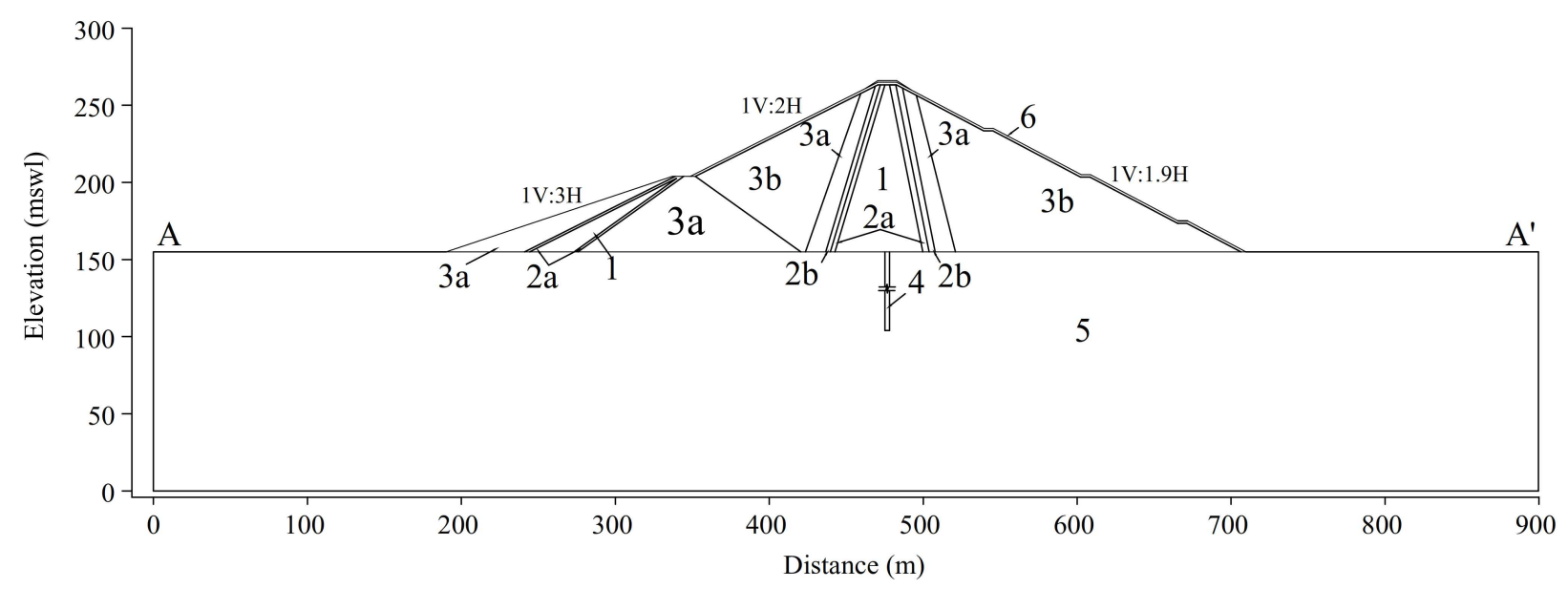

Figure 2: Cross section A-A' of the Jatigede Dam.

Table 1: Engineering properties of the Jatigede Dam (SWHI, 2013).

\begin{tabular}{|c|c|c|c|c|c|c|c|c|}
\hline & Zone & 1 & $2 a$ & $2 b$ & $3 a$ & $3 b$ & 4 & 5 \\
\hline \multicolumn{2}{|c|}{ Model material } & \multicolumn{7}{|c|}{ Mohr-Coulomb } \\
\hline \multirow{4}{*}{ 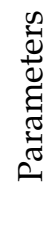 } & $\gamma\left(\mathrm{kN} / \mathrm{m}^{3}\right)$ & 15 & 22 & 23 & 22 & 21.5 & 26 & 26 \\
\hline & $c(\mathrm{kPa})$ & 20 & 30 & 30 & 40 & 40 & 1100 & 1100 \\
\hline & $\phi\left(^{\circ}\right)$ & 18 & 36 & 38 & 36 & 36 & 35 & 35 \\
\hline & $k(\mathrm{~cm} / \mathrm{s})$ & $5 \times 10^{-6}$ & $6.5 \times 10^{-4}$ & $3.6 \times 10^{-3}$ & 1 & 1.7 & $1 \times 10^{-10}$ & $1 \times 10^{-4}$ \\
\hline
\end{tabular}




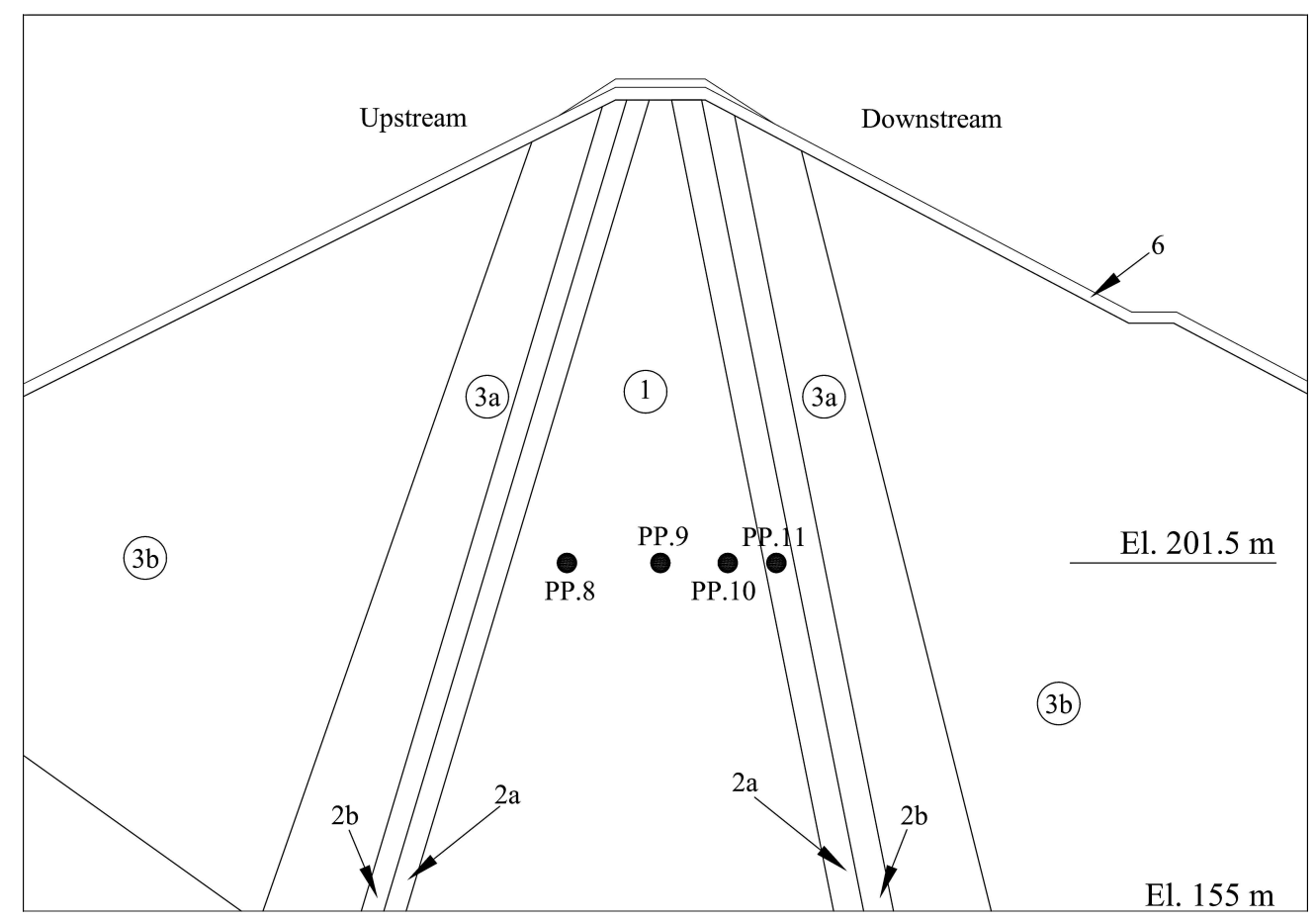

Figure 3: Piezometer installation area.

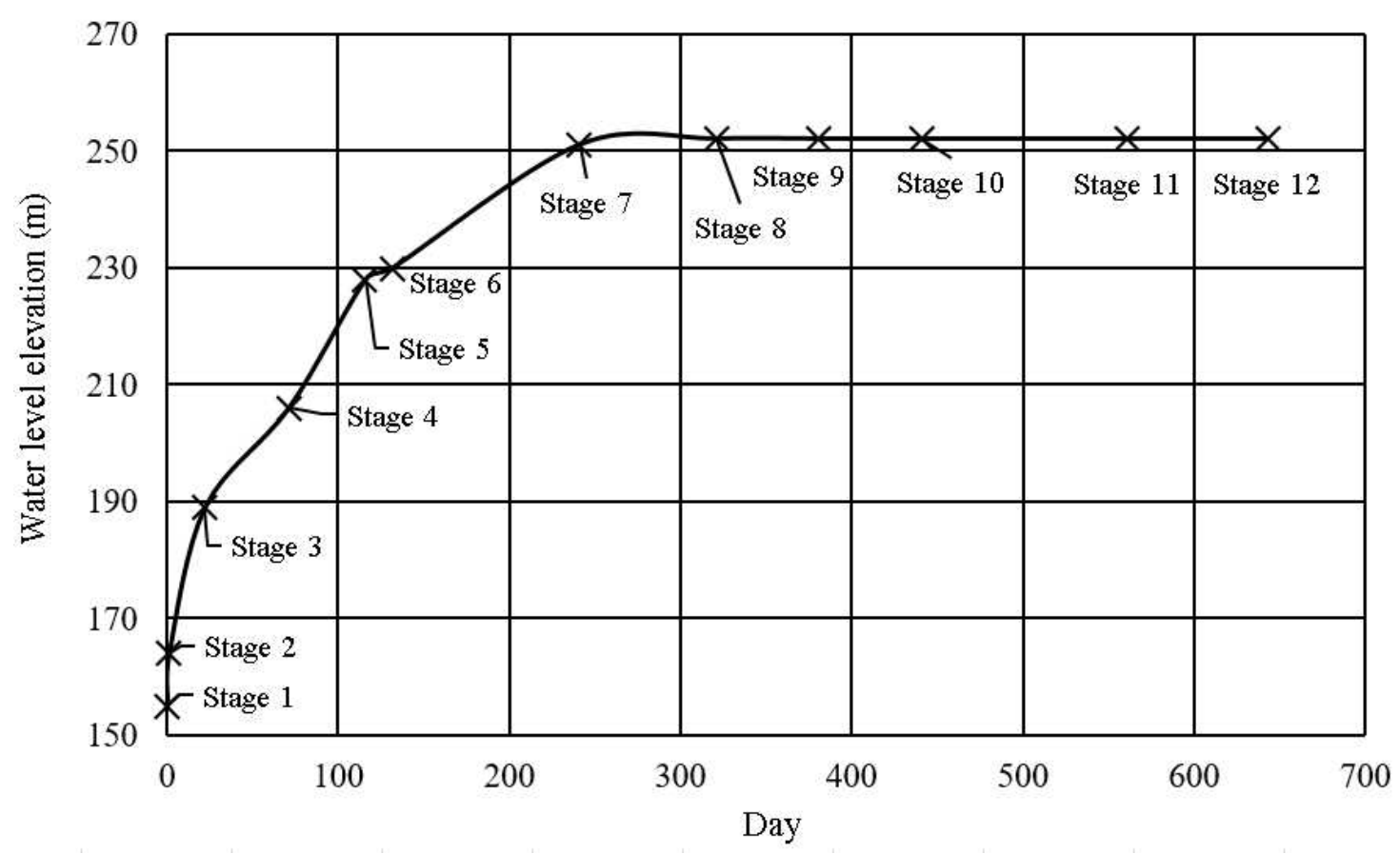

Figure 4: Boundary conditions of seepage analysis. 
meability to the areas with lower permeability (Casagrande, 1937).

The results of analysis in Figure 5 have the same pattern as the results of monitoring in Figure 6 . The difference is in the value of pore water pressure at the first impounding. The change in the pore water pressure is influenced only by the fluctuations of the reservoir water level; therefore, before the impounding takes place, the value of pore water pressure at the end of the construction is almost zero. Meanwhile, the changes in pore pressure monitoring results are influenced by other factors such as infiltration of rainwater during the construction period and dam water table. As a result, the monitored pore water pressure at the end of the construction is greater than the pore water pressure resulted from the analysis. The results of the analysis that are not much different from the results of monitoring show that the changes of pore pressure can be used to evaluate the stability of the dam slope.

\subsection{The analysis of slope stability}

The aim of the slope stability analysis is to determine the safety factor of the Jatigede Dam during reservoir impounding. The safety factor is defined as a ratio of average shear strength of the soil and average shear stress developed along the potential failure surface (Das, 2010). The analysis was conducted using the limit equilibrium method with the Morgenstern-Price method. The pore water pressure change resulted from the seepage analysis was used in the slope stability analysis. Figure 7 shows the results of safety factor analysis on the upstream and downstream slopes of the dam during reservoir impounding. The stage of water level in Figure 7 is transient boundary condition from seepage analysis (Figure 4) in which stage 1 is the end of construction condition.

\subsubsection{Safety factor of the upstream slope}

The analysis results in Figure 7 show that the safety factor changes during the impounding process. At the second stage (first impounding), the safety factor of the upstream slope decreases from 2.11 to 1.94 . One of the critical phases in the reservoir impounding was the first impounding (Cojean and Cai, 2011). During the first impounding, the dam slope, which was initially dry, became saturated due to the rise of the reservoir water level. This caused an increase in pore water pressure at the toe of the cofferdam which led to a decrease in the shear strength of soil. As seen in Figure 8, the slip surface which was initially on the slope of the dam body moves to the cofferdam slope.

At stage 3, the safety factor of the slope is the same as the safety factor at the end of construction. The impervious zone in cofferdam caused the seepage move downward. Consequently, the pore pressure of the cofferdam slope did not change significantly. On the other hand, the rise of water level increased the hydrostatic pressure on the slope surface which contributed to the increase in the safety factor of the cofferdam slope.

At stage 4 and stage 5 , the safety factor decreases during the rise of reservoir water level. The seepage flow caused the pore water pressure in the dam slope to change significantly. As seen in Figure 8, the total head value which was initially $155 \mathrm{~m}$ changed to $230 \mathrm{~m}$. This is the reason why the safety factor of the slope decreased.

In stage 6 and stage 7 , there is an increase in the safety factor because the pore water pressure does not change significantly as shown in Figure 8. This is due to the increase in reservoir water level that occurred for a long time, prompting an insignificant change in the pore water pressure.

In stage 8 to stage 12 , there is no change in the safety factor because the reservoir water level did not change. The reservoir water level condition that did not change for a long time caused the seepage flow on the upstream side of the dam to be almost in a steady state condition although on the other side of the dam, the changing process of the pore pressure was still ongoing. A stable pore pressure did not cause any change in the safety factor for the slope.

The analysis results in stages 5 through 12 provide similar results to the research conducted by Fathani (2012) where the rise of water level increases the safety factor of the upstream slope. The difference that occurs in stage 1 to stage 5 was because the seepage was still in transient conditions while in stage 6 to stage 12 the seepage on the upstream slope of the dam was almost in a steady state condition 
Determination of Stability DuRING First IMPOUNDing IN JATIGEDE EARTH DAM

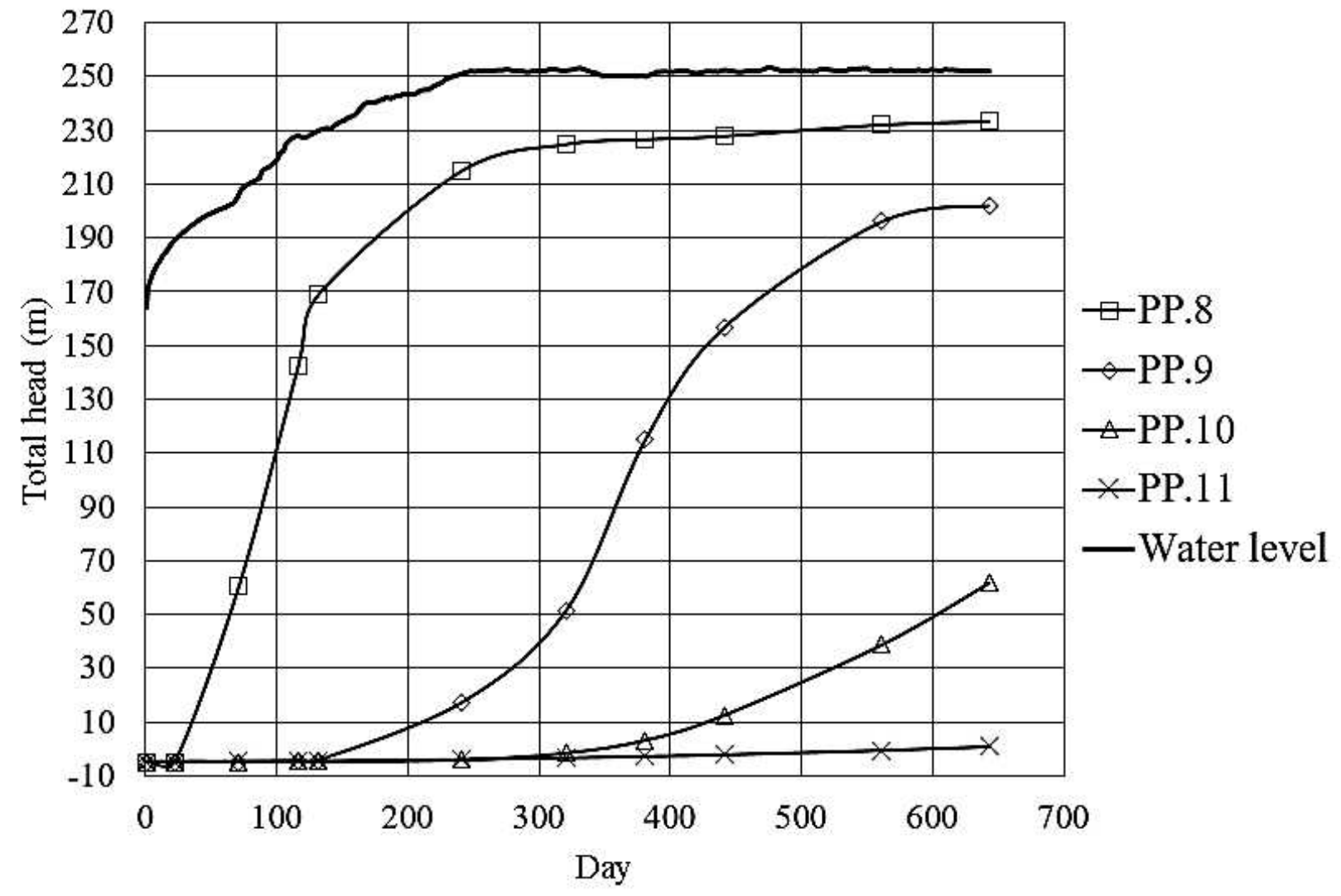

Figure 5: The result of seepage analysis.

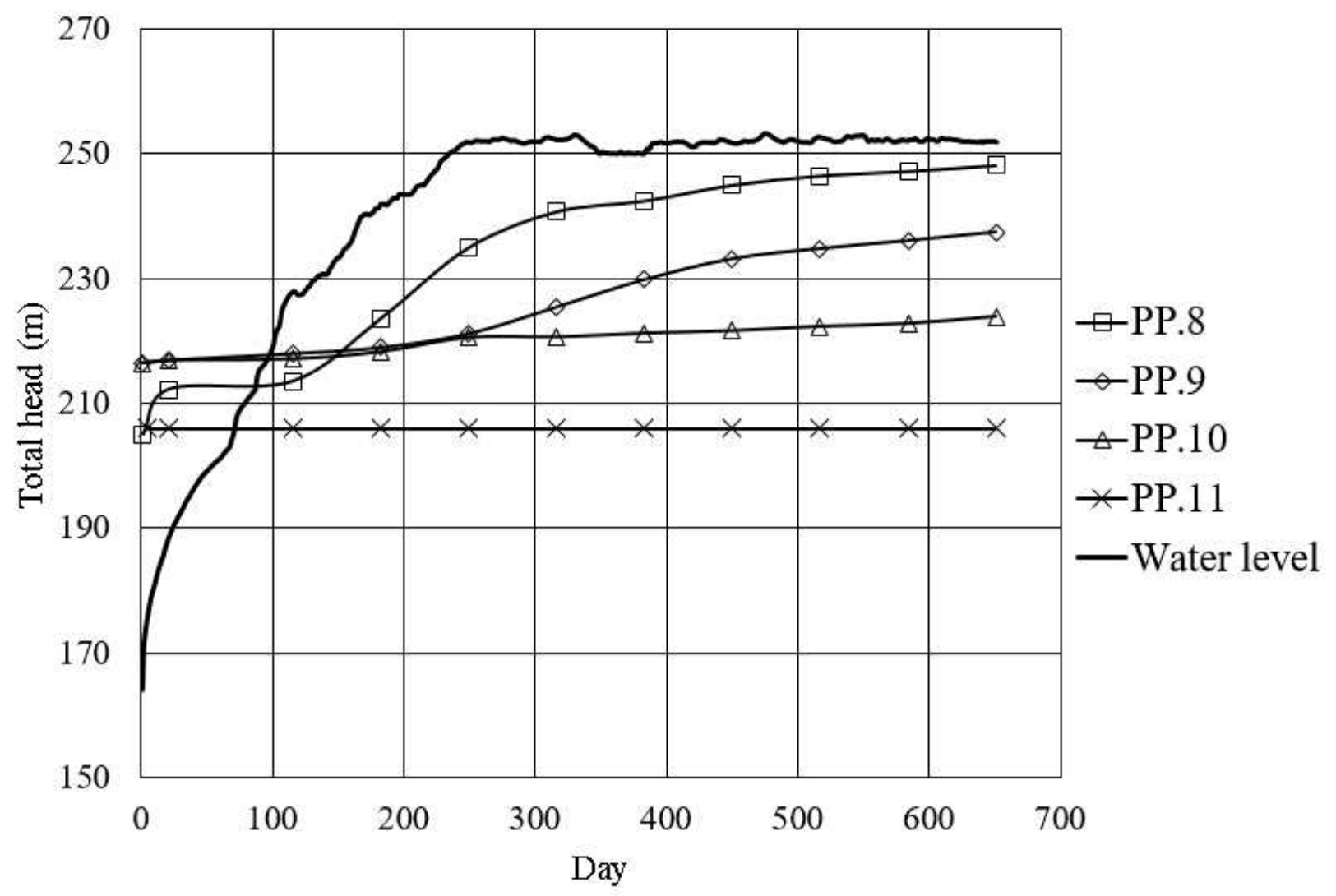

Figure 6: The result of seepage monitoring. 


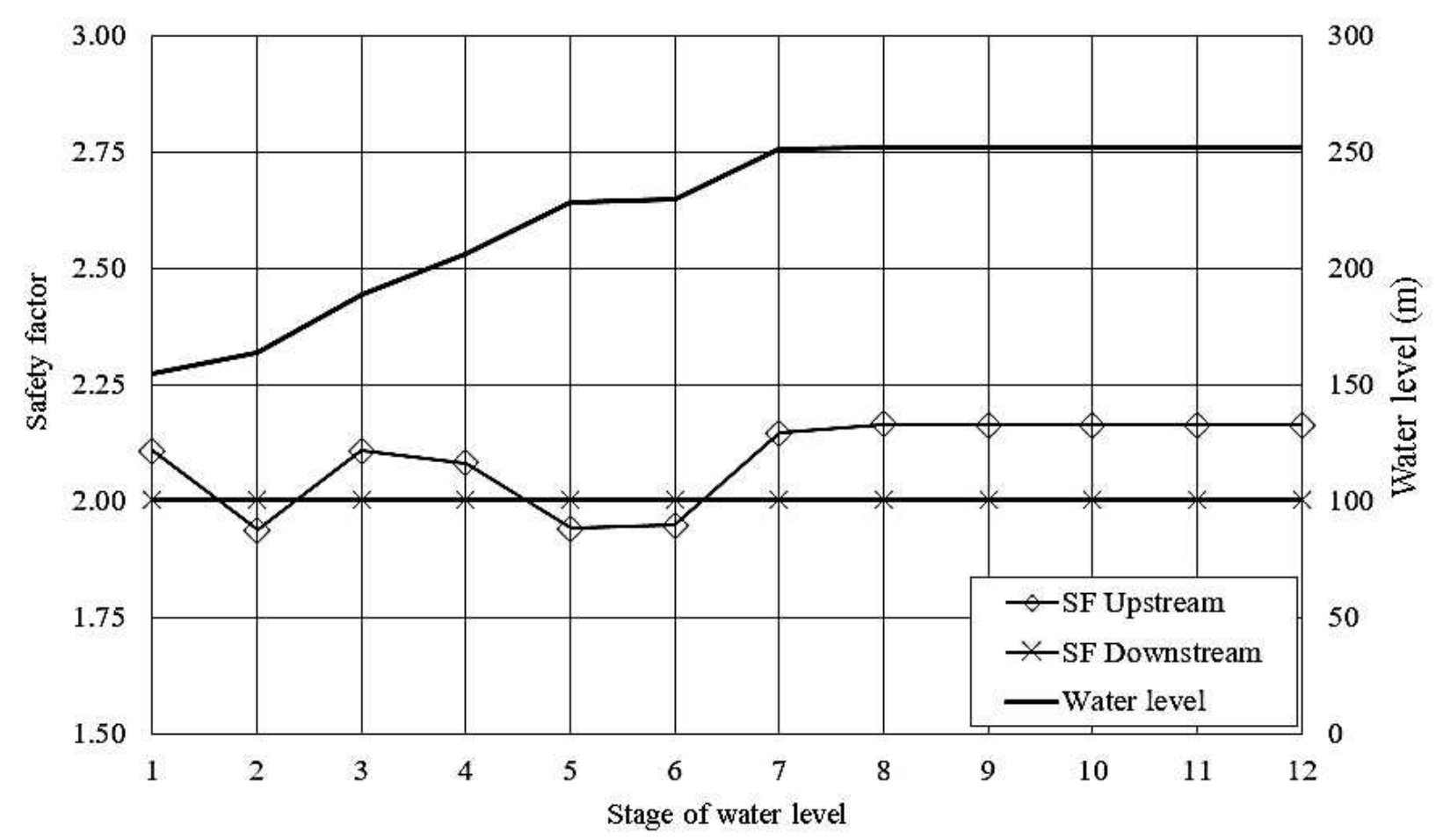

Figure 7: Analysis result of slope stability.
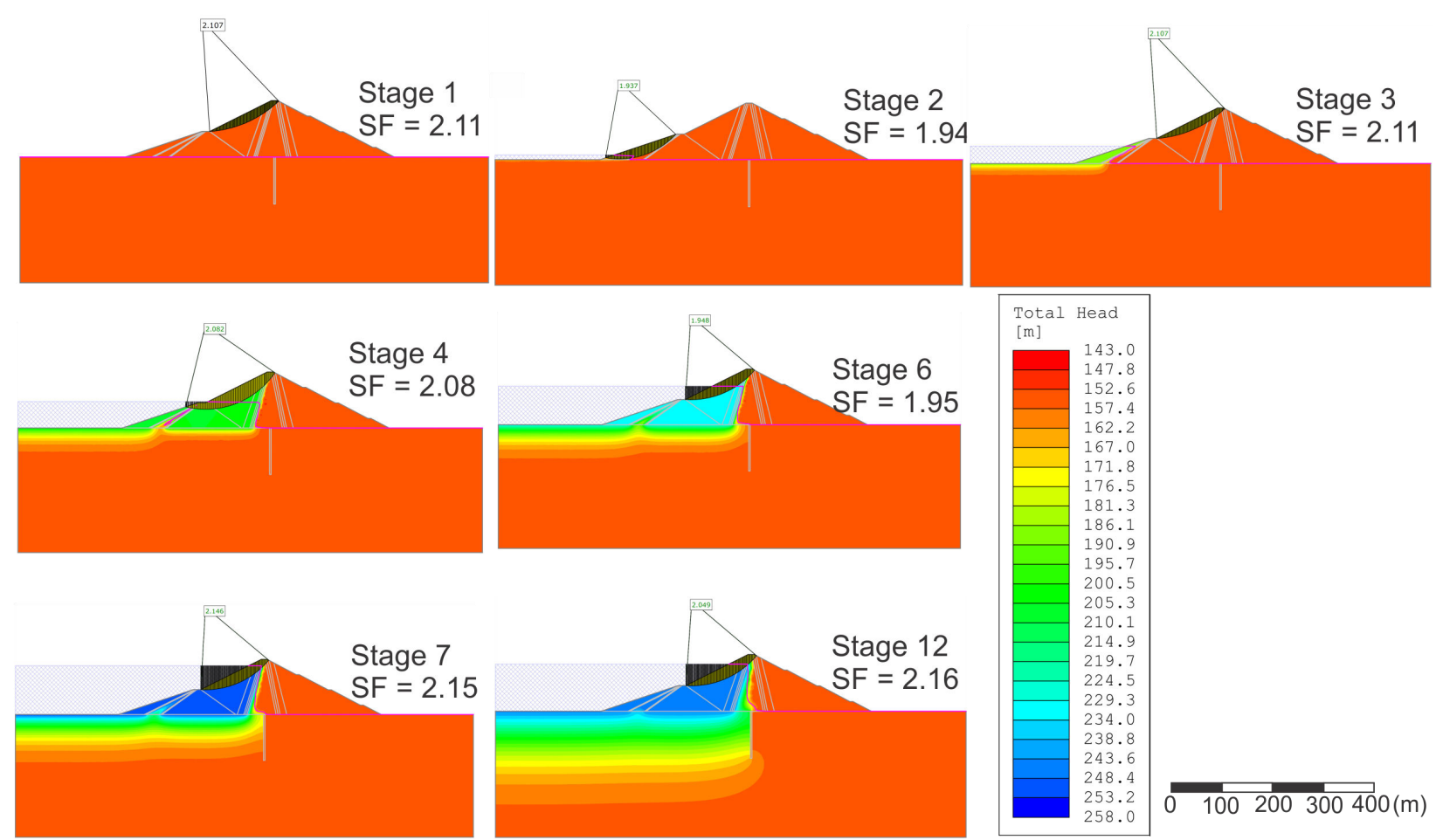

Figure 8: Safety factor of the upstream slope. 
as the change in water level took place for a long time.

\subsubsection{Safety factor of the downstream slope}

The analysis results in Figure 7 show that safety factor of the downstream slope remains constant during reservoir impounding. This is because the impermeable layer in the center of the dam makes the phreatic surface unable to pass through the failure surface of the downstream slope during the impounding as shown in Figure 9. As a result, the safety factor of the slope during reservoir impounding did not change.

The analysis result in Figure 7 provides different results compared to the laboratory studies conducted by Fathani and Legono (2011); Fathani and Legono (2012) where the rise of water level decreases the safety factor of the downstream slope. The research carried out by Fathani and Legono (2011); Fathani and Legono (2012) used a homogeneous dam model so that seepage passes through the failure surface of the dam slope and triggers instability in the downstream slope while in this research, the division of the dam zone with impermeable layer at the center of the dam causes the seepage flow unable to pass through the failure surface of the downstream slope. As a result, the rises of water level does not affect the stability of the downstream slope during resevoir impounding.

The analysis results in Figure 7 show that when the seepage is almost in a steady state condition (stage 7 to stage 12), the safety factor of upstream slope is greater than that of the downstream slope. The resisting effect of the reservoir water on the upstream slope causes an increase of safety factor (Kutzner, 1997; Himanshu and Burman, 2017). Based on the analysis result, all safety factors obtained for the upstream and downstream slope during the impounding process still meet the minimum safety factor criteria required by SNI 8064:2016. Those result mean that the dam is stable in all stages during the impounding process.

\section{CONCLUSION}

Based on the results of seepage analysis and monitoring, it can be concluded that during the first reservoir impounding, changes in pore water pressure only occur on the upstream slope of the dam. The impermeable layer in the center of the dam makes the seepage flow unable to pass through the downstream side of the dam. The results of the analysis show the same pattern of increase in pore pressure compared to the results of monitoring. The difference in the value of pore water pressure is due to the differences in pore water pressure at the end of construction. Therefore, it is acceptable to use changes in pore water pressure during filling of the reservoir to determine the safety factor of the slope.

In the analysis of slope stability, it can be concluded that the safety factor of the slope changes during the process of reservoir impounding. The critical stage of the reservoir impounding process occurs at the first of reservoir impounding as there is a change in the condition of pore water pressure from dry slope to saturated. Finally, it causes a decrease in shear strength on the slope of the dam. On the downstream slope of the dam, there is no change in the safety factor since the end of the construction and during the reservoir impounding because the seepage flow does not pass through the failure surface of downstream slope. All the safety factors obtained during reservoir impounding still meet the minimum required of safety factor criteria.

\section{ACKNOWLEDGEMENTS}

The authors would like to express their gratitude to the Head of Balai Besar Wilayah Sungai (BBWS) Cimanuk Cisanggarung and Satuan Non Vertikal Tertentu (SNVT) of the Jatigede Dam that had assisted the researchers during the data collection process. The researchers also highly appreciate the support of the Computing Laboratory of the Department of Civil and Environmental Engineering, Universitas Gadjah Mada.

\section{REFERENCES}

Abramson, L. W., Lee, T. S., Sharma, S. and Boyce, G. M. (2002) Slope Stability and Stabilization Method. $2^{\text {nd }}$ Ed. New York: John Wiley \& Sons.

Afiri, R. and Gabi, S. (2018) Finite element slope stability analysis of Souk Tleta dam by shear strength reduction technique. Innovative Infrastructure Geotechnology, pp. 1-10.

Andreea, C. (2016) Unsaturated Slope Stability and Seepage Analysis of a Dam. Energy Procedia, pp. 93-98. 

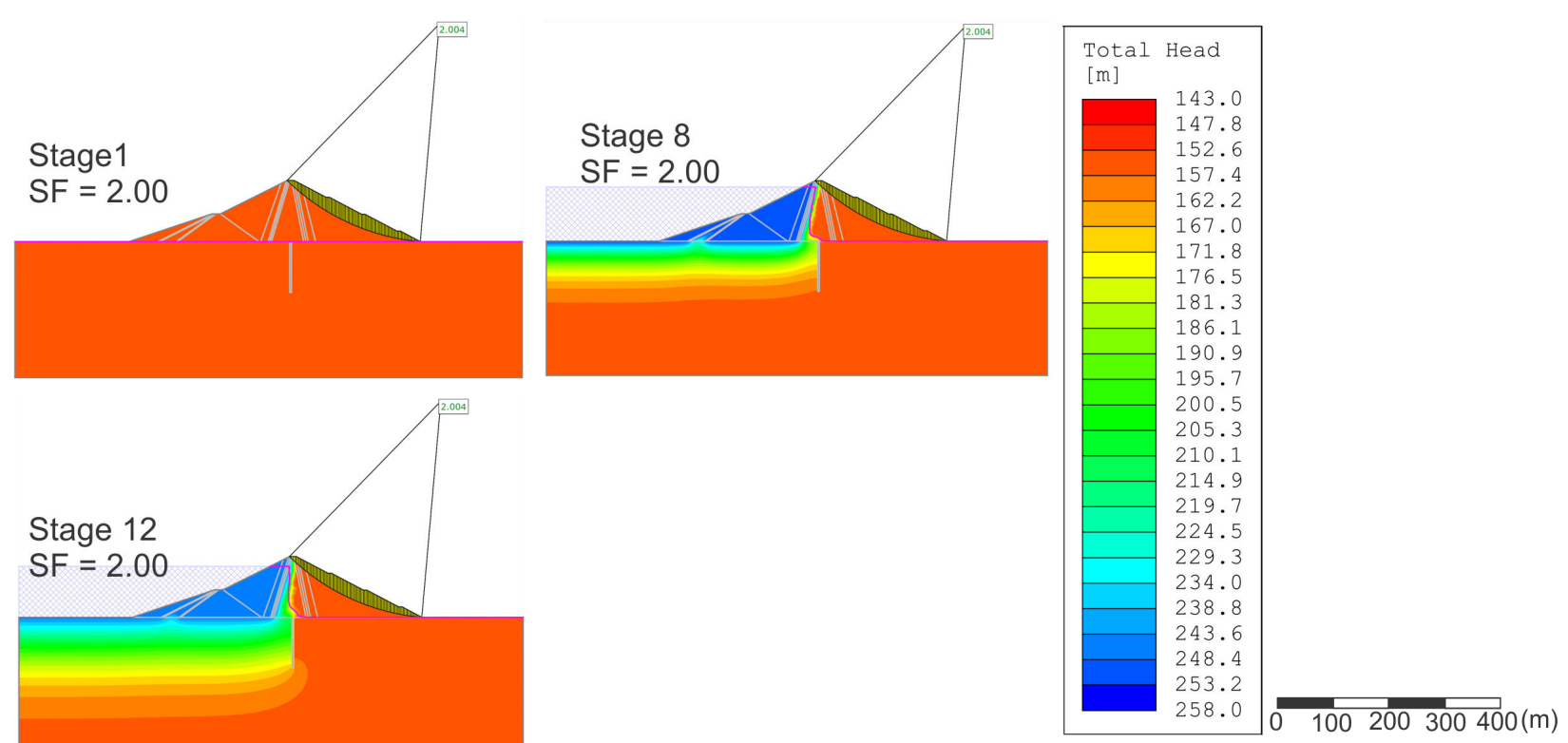

Figure 9: Safety factor of the downstream slope.

Bishop, A. (1954) The use of slip circle in the stability analysis of slope. Geotechnique, pp. 7-17.

Casagrande, A. (1937) Seepgae through Dams. Journal of the New England Water Works Associations, pp. 131-172.

Cojean, R. and Cai, Y. (2011) Analysis and Modeling of Slope Stability in the Three-Gorges Dam Reservoir (China)-The Case of Huangtupo Landslide. Journal of Mountain Science, Volume 8, pp. 166-175.

Craig, R. (2004) Craig's Soil Mechanics. London: Spon Press. Das, B. M., 2010. Principles of Geotechnical Engineering. 7th ed. Stamford: Cengage Learning.

Fathani, T. F. (2012) Study on instability process and failure mechanism of situ gintung earth dam. Proc. of the $10^{\text {th }}$ Anniversary of ICL, pp. 65-71.

Fathani, T. F. and Legono, D. (2011) Seepage and stability analysis of earth dam due to the rising of upstream water level. Proc. of Seminar Teknik, Faculty of Engineering, Universitas Gadjah Mada, pp. D-61-D66.

Fathani, T. F. and Legono, D. (2012) Dynamics of Earth Dam Stability caused by Rapid Rasing and Drawdown of Water Level. Proceedings of The $3^{\text {rd }}$ International Workshop On Multimodal Sediment Disasters, pp. E11-E18.

Fredlund, D. and Rahardjo, H. (1993) Soil Mechanics For Unsaturated Soils. Canada: John Wiley \& Sons.

Himanshu, N. and Burman, A. (2017) Seepage and Stability Analysis of Durgawati Earthen Dam: A
Case Study. Indian Geotechnical Journal, pp. 120.

Iverson, R. M. (2000) Landslide triggering by rain infiltration. Water Resources Research, Volume 36, pp. 1897-1910.

Janbu, N. (1973) Slope stability computations. In: Embankment dam-engineering. New York: Wiley, pp. 47-86.

Kohv, M. and Hang, T. (2013) Pore Pressure Fluctuations Within Quasi-Stable Slopes in SouthWestern Estonia and Their Influence on Slope Stability. Landslide Science and Practice, pp. 7985.

Kutzner, C. (1997) Earth And Rockfill Dams. Rotterdam: A.A. Balkema.

Morgenstern, N. and Price, V. (1965) The analysis of the stability. Geotechnique, 15(1), pp. 79-93.

Picarelli, L., Urcioli, G. and Russo, C. (2003) Effect of groundwater regime on the behaviour of clayey slopes. Canadian Geotechnical Journal, pp. 467-484.

Rulon, J. J. and Freeze, R. A. (1985) Mulitple seepage faces on layered slopes and their implication for slope-stability analysis. Canadian Geotechnical Journal, pp. 347-356.

SNI 8064:2016 (2016) Metode Analisis Stabilitas Lereng Statik Bendungan Tipe Urugan. Jakarta: Badan Standarisasi Nasional.

Spencer, E. (1967) A method of the analysis of the stability of embankments assuming parallel interslice forces. Géotechnique, pp. 11-26.

SWHI (2013) Jatigede Dam Project Design Sum- 
mary Report, P.R. China: Sichuan Water Resources and Hydroelectric Investigation.

Thong, N. H. (2013) Development of Slope Mass Stability Assessment In Tropical Region Around Jatigede Dam Project, Sumedang Regency, West Java, Indonesia, Yogyakarta: Universitas Gadjah Mada.
Yuewe, L., Huixin, C., Qingquan, L., Xin, G., Dawei, Z., Lianxiang, L. (2005) Experimental study on pore pressure in rock-soil slope during reservoir water level fluctuation. Engineering and Material Science, Volume 48, pp. 196208. 